IdeAs

Idées d'Amériques

$17 \mid 2021$

Villes et culture dans les Amériques

\title{
Introduction. A brief overview of "American Studies" in Western Europe
}

Serge Jaumain and Sonia Lehman-Frisch

\section{OpenEdition}

1 Journals

Electronic version

URL: https://journals.openedition.org/ideas/10984

DOI: 10.4000/ideas.10984

ISSN: 1950-5701

Publisher

Institut des Amériques

Electronic reference

Serge Jaumain and Sonia Lehman-Frisch, "Introduction. A brief overview of "American Studies" in Western Europe", IdeAs [Online], 17 | 2021, Online since 01 March 2021, connection on 03 June 2021. URL: http://journals.openedition.org/ideas/10984 ; DOI: https://doi.org/10.4000/ideas.10984

This text was automatically generated on 3 June 2021

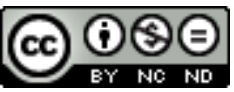

IdeAs - Idées d'Amériques est mis à disposition selon les termes de la licence Creative Commons Attribution - Pas d'Utilisation Commerciale - Pas de Modification 4.0 International. 


\title{
Introduction. A brief overview of "American Studies" in Western Europe
}

\author{
Serge Jaumain and Sonia Lehman-Frisch
}

Les auteurs de ce dossier tiennent à remercier très chaleureusement Donna Kesselman, membre du comité de rédaction de IdeAs, et Isabelle Vagnoux, co-rédactrice en chef de la revue, pour les améliorations linguistiques apportées aux textes présentés ici.

1 Scholars from several European institutions specialized in American studies, gathered in a round table discussion at the last Institut des Amériques (IdA) congress held in Paris in 2019, discussed the possibility of federating various national research initiatives with the aim of structuring American studies in Europe at the continental scale. It was noted that there has not never been a European-wide assessment of American studies. We therefore took the opportunity offered by the "Eclairages" section of IdeAs: Idées d'Amériques to present a brief overview of how American studies are organized in a few European countries (France, Italy, United Kingdom, Spain, Belgium, Germany). Far from aiming at any exhaustive account, the survey articles compiled here offer initial insight into American studies in Europe, providing valuable insight into the main trends that portray the educational and scholarly landscape.

2 First of all, the texts clearly reveal to what extent the Americas are rarely perceived as a whole. The geolinguistic fault line that disassociates work on North America (United States and Canada) from Latin America is indeed old and deeply engrained at the institutional level, as evidenced by the number of research centers and organizations whose activities focus exclusively on either one of these two regions. In most of the countries studied, the term "American studies" often refers to research on North America, or even only the United States, omitting Canada.

3 The texts attest as well to the vitality of research on the Americas, especially since the end of the Second World War. The far-reaching programs of scholarships, chairs, library grants, and financial aid offered by U.S. government agencies have played a major role in the formidable development of academic initiatives adressing this 
country and no doubt explain why it has often tended to overshadow others in the field of "American studies". It is in part to resist this academic expansionism that, from the mid-1980s onward, other governments in the hemisphere implemented similar initiatives: Canada, for example, developed a skillful international strategy to promote Canadian studies that fostered the birth and development of Canadian studies centers and associations around the world, particularly in Europe.

Direct financial support for research by the countries of the Americas cannot explain as such the European enthusiasm for American studies. The six country studies presented here bring to light other compelling factors: the geostrategic role of the United States, the archaeological wealth of Central America, the intimate historical links that bind countries and societies across continents. Spain, the United Kingdom and France, of course, come to mind, the former colonizers whose history and national languages nourish inquisitiveness in certain parts of the Americas. There is also Italy, whose migratory movements are an integral part of American studies, just as relations between the Vatican and the Catholic communities established throughout the continent. In addition to these scholarly endeavors, the flourishing initiatives devoted to academic exchanges - increased mobility of students and researchers - have also contributed to the continuously renewed interest in this region of the world.

5 American Studies are far from being a uniform field: the following contributions display a wide variety of critical concerns regarding any particular region or country of the Americas, and this from one European country and discipline to another. Moreover, many researchers are reluctant to engage in cross-border analysis between North and Latin America, even though the desire to develop a transAmerican approach transcending these regional boundaries has been on the agenda for nearly two decades. It has been advanced through institutional initiatives and innovative projects, that focus on border studies and the development of transatlantic approaches and/or the circulation of goods, people and ideas. These emerging representations that propose to apprehend the Americas as a coherent entity, led to the development of structures such as the Institut des Amériques in France or the AmericaS center in Brussels.

6 Finally, the institutional perspective adopted by the contributions presented here should not overlook the fact that the specialized area studies centers reflect only part of the academic work carried out_on the Americas. A wide range of education and research on this region of the world takes place within disciplinary departments and research bodies and is therefore not included within the scope of the institutions representing "area studies".

7 All in all, despite its deliberately limited scope, the overview provided by the following contributions illustrates the dynamism and renewal of American studies in the six countries considered. It implicitly argues for the development of a European approach to American studies at a more overarching level and underlines the value of pursuing the initial results outlined by extending the survey to the rest of Europe, particularly to Central and Eastern Europe. 


\section{AUTHORS}

\section{SERGE JAUMAIN}

Serge Jaumain is professor of Contemporary History at the Université libre de Bruxelles (ULB). He is co-director, with Prof. Frédéric Louault of the Interdisciplinary Center for the Study of the Americas (AmericaS), President of the Scientific Council of the Agence universitaire de la Francophonie and member of the Scientific Council of the Institut des Amériques. His research focuses mainly on North American history, French speaking migration to Canada and Tourism History.

\section{SONIA LEHMAN-FRISCH}

Sonia Lehman-Frisch est professeure de géographie à l'Université Paris Nanterre, chercheure à l'UMR LAVUE 7318 (équipe Mosaïques). Spécialiste des villes états-uniennes et de San Francisco en particulier, ses recherches portent sur les processus de gentrification et de ségrégation, les questions d'inégalités et de justice spatiale, et les rapports des habitants au quartier et à la ville (notamment celui des enfants). Elle a récemment publié Sociologie de San Francisco aux éditions La Découverte (2018). 